\section{Exudative age- related macular degeneration treated by intravitreal triamcinolone acetonide. A prospective comparative nonrandomized study}

JB Jonas, RF Degenring, I Kreissig, T Friedemann and I Akkoyun
Conclusions Visual acuity increased in patients with exudative age-related macular degeneration at 1 month and 3 months after an intravitreal injection of $25 \mathrm{mg}$ triamcinolone acetonide.

Eye (2005) 19, 163-170. doi:10.1038/sj.eye.6701438 Published online 25 June 2004

Keywords: exudative age-related macular degeneration; intravitreal triamcinolone acetonide; intraocular pressure; steroid response; macular disease; maculopathy

\section{Introduction}

Age-related macular degeneration is one of the most common irreversible causes of severe loss of vision in the elderly population in Western countries. ${ }^{1-3}$ Despite its high importance for quality of life of the individual patient and its marked socio-economic impact on the society, treatment of age-related macular degeneration has remained unclear for many patients with the exudative type of age-related macular degeneration..$^{4-6}$ The purpose of the present study was to investigate whether the antiangiogenetic, antiproliferate, and antioedematous effect of intravitreal triamcinolone acetonide can be used to treat patients with exudative age-related macular degeneration. Since previous studies as well as
Department of Ophthalmology Faculty of Clinical Medicine Mannheim of the University Heidelberg, Germany

Correspondence: JB Jonas Universitäts-Augenklinik Theodor-Kutzer-Ufer 1-3 68167

Mannheim, Germany; Tel: +496213832242 or +496213832652 Fax: +496213833803

E-mail: Jost.Jonas@ ma.augen.uni-heidelberg.de

Received: 5 November 2003 Accepted in revised form: 6 June 2004 Published online: 25 June 2004

Proprietary interest: none 
clinical experience have shown that topical, oral, or intravenous application of cortisone in systemically tolerable concentrations has not resulted in cure of the disease, ${ }^{1}$ we chose the intraocular injection of cortisone to obtain high levels of steroids at the site of required action without provoking major systemic side effects. Since soluble cortisone is washed out of the eye within $24 \mathrm{~h}$ after intraocular application, ${ }^{7}$ we took crystalline cortisone (triamcinolone acetonide), which remains in the eye for 2-9 months after a single intravitreal injection. ${ }^{8-10}$

\section{Patients and methods}

The clinical interventional prospective comparative nonrandomized study included 187 patients (187 eyes) (115 women; 96 right eyes) with progressive decrease of visual acuity due to exudative age-related macular degeneration. The patients of the study group consisting of 115 patients ( 115 eyes) (74 women; 55 right eyes) consecutively received an intravitreal injection of $25 \mathrm{mg}$ triamcinolone acetonide as the only treatment. For those patients who received the intravitreal injection into both eyes, one randomly chosen eye was taken for inclusion into the study. The patients of the control group included 72 patients (72 eyes) (41 women; 41 right eyes) who did not receive an intravitreal injection of triamcinolone nor any other treatment for exudative age-related macular degeneration. The reason for assigning patients to the study group or the control group was that the patients of the control group did not want to get an intravitreal injection although it was offered to them in the same way as to the patients of the study group. The study was performed at a university hospital.

For all patients, visual acuity at baseline of the study ranged between 0.02 and 0.50 . During the follow-up, no additional ocular surgery including cataract operation was carried out. Fluorescein angiography performed for all patients revealed a subfoveal choroidal neovascularization. For all patients of the study, no different treatment was possible since either verteporfin photodynamic therapy was not indicated or the patients refused photodynamic therapy due to reasons such as costs or the necessity for repeated treatments. Surgical macular rotation was either denied by the patients or by an external surgeon experienced in macular rotation whom some of the patients were referred to.

Owing to the distribution of patients into the study group and the control group, both groups did not vary significantly in preoperative visual acuity $(P=0.67)$, preoperative intraocular pressure $(P=0.44)$, age $(P=0.11)$, refractive error $(P=0.36)$, gender $(P=0.18)$, and right or left eye $(P=0.24)$ (Table 1$)$. All patients were fully informed about the experimental character of the treatment. All patients signed an informed consent. The
Table 1 Baseline data of the patients of the study group and the control group (mean $\pm S D$ ); $P$-value: statistical significance of difference between the two groups; n.s.: statistically not significant

\begin{tabular}{llll}
\hline & Study group & Control group & P-value \\
\hline$n$ & 115 & 72 & \\
Age (years) & $77.9 \pm 7.3$ & $76.0 \pm 7.4$ & 0.11 (n.s.) \\
Range & & $58.0-100.1$ & $58.0-93.4$ \\
Median & & 78.4 & 77.2 \\
Females/males & $74 / 41$ & $41 / 31$ & 0.18 (n.s.) \\
Right eye/left eye & $55 / 60$ & $40 / 32$ & 0.24 (n.s.) \\
Refractive error $(D)$ & $0.82 \pm 2.10$ & $0.72 \pm 2.14$ & 0.36 (n.s.) \\
Median & & 0.75 & 0.19 \\
Range & -7.0 to +7.0 & -5.50 to +7.25 & \\
Visual acuity & $0.17 \pm 0.11$ & $0.20 \pm 0.15$ & 0.67 (n.s.) \\
Median & 0.20 & 0.20 & \\
Range & $0.02-0.50$ & $0.02-0.50$ & \multirow{2}{*}{0.44 (n.s.) } \\
Intraocular pressure & $15.3 \pm 2.9$ & $15.8 \pm 3.5$ & \\
\hline
\end{tabular}

Ethics Committee of the University had approved the study, which followed the tenets of the Declaration of Helsinki.

All patients received an intravitreal injection of $25 \mathrm{mg}$ crystalline triamcinolone acetonide in $0.2 \mathrm{ml}$ Ringer's solution as previously described in detail. Prior to the intravitreal injection, topical Betadine ${ }^{\mathrm{R}}$ (povidone-iodine 5\%) (Alcon, Ft Worth, TX, USA) was applied, and after that the patients were completely draped. A lid speculum was inserted and a paracentesis was carried out to decrease the volume of the eye. The injection of $25 \mathrm{mg}(0.2 \mathrm{ml})$ crystalline triamcinolone acetonide was performed through a sharp 27-gauge needle through the inferior pars plana, at 3-3.5 mm from the limbus. After that, an antibiotic ointment (polymyxin and neomycine) was applied. The triamcinolone acetonide had been prepared by extracting $0.625 \mathrm{ml}$ from the ampoule (Volon $\mathrm{A}^{\mathrm{R}}$, Bristol-Myers-Squibb, Germany) containing $40 \mathrm{mg}$ of triamcinolone acetonide in $1 \mathrm{ml}$. The extracted volume was filled into a tuberculin syringe $(1 \mathrm{ml})$ or a $2 \mathrm{ml}$ syringe. The syringe was filled up with Ringer's solution. A millipore filter (pore size, $5 \mu \mathrm{m}$ ) was placed on top of the syringe, and most of the content of the syringe was pressed through the filter, with the triamcinolone acetonide crystals remaining in the syringe. The syringe was re-filled with Ringer's solution, and the same procedure was repeated three times. At the end, $0.2 \mathrm{ml}$ of solution in the syringe was left, and using a 27-gauge needle, the content was injected transconjunctivally into the vitreous cavity.

At baseline of the study in all patients, visual acuity, and intraocular pressure were determined and fluorescein angiography was performed. After inclusion into the study, the patients of the study group and the control group were re-examined. The patients of the 
study group were re-examined the first day after injection, followed by re-examinations at about 1-month intervals. The patients of the control group were reexamined in roughly 2 months intervals. There were markedly smaller control subgroups at the reexamination at 1,2, and 3 months after start of the study (Table 2). The mean follow-up was $6.0 \pm 4.2$ months (1.022.7 months). Visual acuity was determined in a standardized manner by an observer performing bestcorrected refractometry and using Snellen charts.

Statistical analyses were performed by using a commercially available statistical software package (SPSS for Windows, version 11.5, SPSS, Chicago, IL, USA). To test the statistical significance of differences between the study group and the control group, the Mann-Whitneytest, Wilcoxon-test, or Student's-t-test for parameters such as intraocular pressure and visual acuity were used. For parameters, such as gender and right or left eye, the $\chi^{2}$-test was applied. The level of significance was 0.05 (two-sided) in all statistical testing.

\section{Results}

In the study group, an increase of best visual acuity during the follow-up was found in $72(62.6 \%)$ patients, and a decrease in 21 (18.3\%) eyes. The change in best visual acuity was on the average $0.05 \pm 0.14$ (Table 2 ), indicating a significant $(P<0.001)$ increase in visual acuity compared to the baseline value. Expressing visual acuity in Snellen units demonstrated a similar result (Table 2). The mean and significant $(P<0.001)$ increase in visual acuity was $1.14 \pm 2.89$ Snellen lines with $43(37.4 \%)$ patients experiencing an increase in best visual acuity by more than one Snellen line. In the control group, best visual acuity changed by $0.02 \pm 0.05$ or by $0.32 \pm 0.78$ Snellen lines (Table 2). The differences in change in best visual acuity between the study group and the control group were significant $(P<0.001)$. Correspondingly, the number of patients showing an increase in visual acuity by more than 1 Snellen line during the follow-up was significantly higher in the study group than in the control group $\left(P<0.001 ; \chi^{2}\right.$-test).

For the measurements taken at 1 month and 3 months after the baseline of the study with a smaller number of patients recruited for those examinations, similar results were obtained (Table 2). In the study group at 1 month after injection, visual acuity had increased significantly $(P=0.03)$ from $0.17 \pm 0.11$ at baseline of the study to $0.21 \pm 0.15(n=93)$. In the control group, visual acuity had decreased significantly $(P=0.01)$ from $0.23 \pm 0.16$ to $0.17 \pm 0.18(n=18)$ (Table 2$)$. The difference between the study and control group in relation to change in visual acuity between baseline of the study and the measurements taken 1 month after the start of the study was significant $(P=0.001)$. In a similar manner, the number of patients demonstrating an improvement of more than 1 Snellen line at 1 month after baseline of the study was significantly $(P=0.001)$ higher in the study group than in the control group. Correspondingly, the number of patients experiencing a decrease in visual acuity of more than 1 Snellen line was significantly $(P=0.007)$ higher in the control group (Table 2$)$.

For the measurements obtained 2 months after start of the study, the differences between the study group and control group were not significant (Table 2).

At 3 months after baseline of the study, similar results were obtained as at 1 month after start of the study. Visual acuity had increased, however not significantly $(P=0.24)$, from $0.16 \pm 0.10$ to $0.19 \pm 0.16(n=68)$ in the study group. In the control group, visual acuity had decreased significantly $(P=0.02)$ from $0.21 \pm 0.15$ to $0.15 \pm 0.15(n=18)$. The difference between the study group and control group in relation to change of visual acuity between baseline and the measurement at 3 months after start of the study was significant $(P=0.007)$ (Table 2).

For the measurements obtained 4 months or later after start of the study, the differences between the study group and control group were statistically not significant. The reason for this may have been that in the study group, the gain in visual acuity was detectable for the first 5 months after the injection, while 6 months or later after the injection, the mean visual acuity was lower than at baseline of the study. Correspondingly, considering the visual acuity measurements taken at the end of followup, patients of the study group and the patients of the control group no longer differed significantly in terms of the change in visual acuity $(-1.4 \pm 4.1$ Snellen lines in the study group vs $-1.6 \pm 3.5$ Snellen lines in the control group; $P=0.94)$.

In the study group, intraocular pressure increased significantly $(P<0.001$; Wilcoxon test) from $15.3 \pm 2.9 \mathrm{~mm}$ $\mathrm{Hg}$ (median, $16 \mathrm{mmHg}$ ) at baseline of the study to a mean maximum of $21.9 \pm 7.2 \mathrm{~mm} \mathrm{Hg}$ (median, $20 \mathrm{mmHg}$ ). In all, $49(43.0 \%)$ eyes developed as maximum at an intraocular pressure higher than $21 \mathrm{mmHg}$. In the control group, intraocular pressure was at baseline of the study $15.8 \pm 3.5 \mathrm{mmHg}$, and the highest intraocular pressure during the follow-up was $16.6 \pm 3.4 \mathrm{~mm} \mathrm{Hg}$, which was significantly $(P<0.00)$ lower than that in the study group.

\section{Discussion}

Intravitreal triamcinolone acetonide has increasingly been used in previous studies as treatment for intraocular proliferative, oedematous, and neovascular diseases, such as diffuse diabetic macular oedema, ${ }^{11-13}$ proliferative diabetic retinopathy, ${ }^{14,15}$ neovascular 
Table 2 Follow-up data of the patients of the study group and the control group (mean $\pm \mathrm{SD}$ ); $P$-value: statistical significance of difference between the two groups; n.s.: statistically not significant

\begin{tabular}{|c|c|c|c|}
\hline & Study Group & Control Group & P-Value \\
\hline$n$ & 115 & 72 & \\
\hline Change in best visual acuity & $0.05 \pm 0.14$ & $0.02 \pm 0.05$ & $<0.001$ \\
\hline Median & 0.03 & 0.00 & \\
\hline Range & -0.40 to 0.60 & 0.00 to +0.30 & \\
\hline Number of eyes increasing in best visual acuity & $72(62.6 \%)$ & $12(16.7 \%)$ & \\
\hline Number of eyes constant in best visual acuity & $22(19.1 \%)$ & $60(83.3 \%)$ & \\
\hline Number of eyes decreasing in best visual acuity & $21(18.3 \%)$ & $0(0 \%)$ & \\
\hline Change in best visual acuity (snellen lines) & $1.14 \pm 2.89$ & $0.32 \pm 0.78$ & $<0.001$ \\
\hline Median & 1.00 & & 0.00 \\
\hline Range & -7 to +15 & 0 to +3 & \\
\hline Number of eyes increasing in best visual activity by $>1$ snellen line & $43(37.4 \%)$ & $8(11.1 \%)$ & \\
\hline Number of eyes constant in best visual activity $(+-1$ snellen line) & $58(50.4 \%)$ & $64(88.9 \%)$ & \\
\hline Number of eyes decreasing in best visual activity by $>1$ snellen line & $14(12.2 \%)$ & $0(0 \%)$ & \\
\hline \multicolumn{4}{|l|}{ Change in visual acuity at 1 month after baseline } \\
\hline$n$ & 93 & 18 & \\
\hline Mean \pm SD & $0.03 \pm 0.13$ & $-0.06 \pm 0.09$ & 0.001 \\
\hline Median & & 0.01 & -0.02 \\
\hline Range & -0.28 to +0.58 & -0.20 to +0.10 & \\
\hline Number of eyes increasing in best visual acuity & $47(50.5 \%)$ & $1(5.6 \%)$ & \\
\hline Number of eyes constant in best visual acuity & $20(21.5 \%)$ & $7(38.8 \%)$ & \\
\hline Number of eyes decreasing in best visual acuity & $26(28.0 \%)$ & $10(55.6 \%)$ & \\
\hline Change in best visual acuity (snellen lines) & $0.68 \pm 3.28$ & $-2.44 \pm 3.75$ & $<0.001$ \\
\hline Median & -2 & & \\
\hline Range & -7 to +15 & -15 to +1 & \\
\hline Number of eyes increasing in best visual activity by $>1$ snellen line & $32(34.4 \%)$ & $0(0 \%)$ & \\
\hline Number of eyes constant in best visual activity $(+-1$ snellen line) & $44(47.3 \%)$ & $9(50.0 \%)$ & \\
\hline Number of eyes decreasing in best visual activity by $>1$ snellen line & $17(18.3 \%)$ & $9(50.0 \%)$ & \\
\hline$n$ & 78 & 18 & \\
\hline \multicolumn{4}{|l|}{ Change in visual acuity at 2 months after baseline } \\
\hline Mean \pm SD & $0.01 \pm 0.12$ & $-0.06 \pm 0.09$ & 0.44 (n.s.) \\
\hline Median & & 0.00 & -0.02 \\
\hline Range & & -0.21 to +0.40 & -0.20 to +0.10 \\
\hline Number of eyes increasing in best visual acuity & $30(38.5 \%)$ & $2(11.2 \%)$ & \\
\hline Number of eyes constant in best visual acuity & $13(16.7 \%)$ & $9(50.0 \%)$ & \\
\hline Number of eyes decreasing in best visual acuity & $35(44.9 \%)$ & $7(38.9 \%)$ & \\
\hline Change in best visual acuity (snellen lines) & $-0.21 \pm 2.94$ & $-2.44 \pm 3.75$ & 0.23 (n.s.) \\
\hline Median & 0 & $-2-1-3$ & \\
\hline Range & -8 to +9 & -15 to +1 & \\
\hline Number of eyes increasing in best visual activity by $>1$ snellen line & $20(25.6 \%)$ & $2(11.2 \%)$ & \\
\hline Number of eyes constant in best visual activity $(+-1$ snellen line) & $31(39.8 \%)$ & $10(55.6 \%)$ & \\
\hline Number of eyes decreasing in best visual activity by $>1$ snellen line & $27(34.6 \%)$ & $6(33.3 \%)$ & \\
\hline \multicolumn{4}{|l|}{ Change in visual acuity at 3 months after baseline } \\
\hline$n$ & 68 & 18 & \\
\hline Mean \pm SD & $0.03 \pm 0.14$ & $-0.06 \pm 0.10$ & 0.007 \\
\hline Median & & 0.00 & -0.02 \\
\hline Range & & -0.22 to +0.60 & -0.24 to +0.10 \\
\hline Number of eyes increasing in best vis. acuity & $31(45.6 \%)$ & $2(11.2 \%)$ & \\
\hline Number of eyes constant in best visual acuity & $17(25.0 \%)$ & $7(38.9 \%)$ & \\
\hline Number of eyes decreasing in best visual acuity & $20(29.4 \%)$ & $9(50.0 \%)$ & \\
\hline Change in best visual acuity (snellen lines) & $0.22 \pm 3.38$ & $-2.56 \pm 4.54$ & 0.01 \\
\hline Median & 0 & -1 & \\
\hline Range & -9 to +9 & -15 to +3 & \\
\hline Number of eyes increasing in best visual activity by $>1$ snellen line & $19(27.9 \%)$ & $2(11.2 \%)$ & \\
\hline Number of eyes constant in best visual activity $(+-1$ snellen line) & $31(45.5 \%)$ & $8(44.4 \%)$ & \\
\hline Number of eyes decreasing in best visual activity by $>1$ snellen line & $18(26.5 \%)$ & $8(44.4 \%)$ & \\
\hline
\end{tabular}


glaucoma without or with cataract surgery, ${ }^{16,17}$ central retinal vein occlusion, ${ }^{18-20}$ proliferative vitreoretinopathy, ${ }^{21}$ chronic pre-phthisical ocular hypotony, ${ }^{22}$ chronic uveitis, ${ }^{23-26}$ persistent pseudophakic cystoid macular oedema, ${ }^{27-29}$ and in other clinical situations. ${ }^{30,31}$ In aqueous humour and in silicone oil, triamcinolone acetonide has been found 8-9 months after the intravitreal injection..$^{8-10}$ Systemic and local side effects, reported so far, include cataract, secondary ocular hypertension leading in some patients to secondary chronic open-angle glaucoma, and postinjection infectious endophthalmitis. ${ }^{32,33}$

For patients suffering from exudative age-related macular degeneration, recent studies have proven that photodynamic therapy is helpful as treatment for the classic type of subfoveal neovascularization. ${ }^{4-6}$ Treatment of exudative age-related macular degeneration with minimally classic subfoveal neovascularization, however, has been inconclusive so far since studies have not demonstrated a marked therapeutic effect of photodynamic therapy. Consequently, other treatment modalities have been investigated, one of which is the intravitreal application of triamcinolone acetonide with its anti-oedematous and antiangiogenic effect, demonstrated in experimental investigations and clinical studies. ${ }^{34-48}$ Penfold et $a l^{38}$ started to inject triamcinolone acetonide intravitreally in an effort to treat exudative age-related macular degeneration medically. ${ }^{40}$ In 1998, Challa $e$ t $a l^{40}$ evaluated the safety and efficacy of intravitreal triamcinolone after a follow-up of 18 months in patients with exudative age-related macular degeneration considered unsuitable for laser photocoagulation. In the nonrandomized clinical pilot study, 30 eyes of 28 patients were treated with an intravitreal injection of triamcinolone $(4 \mathrm{mg})$. Of the 20 eyes with initial visual acuity of 0.10 or better, vision was stabilized in 11 eyes (55\%), while six eyes (30\%) suffered severe visual loss (six or more lines). Visual acuity improved in three of 10 eyes with an initial vision of 3/60 or worse. The authors concluded that a single intravitreal injection of $4 \mathrm{mg}$ triamcinolone may be reasonably well tolerated and helpful in the treatment of exudative agerelated macular degeneration. In a randomized clinical trial, Danis et al. ${ }^{41}$ examined the effects of intravitreal injection of $4 \mathrm{mg}$ triamcinolone acetonide on visual and the clinical course of exudative age-related macular degeneration in 27 patients who were compared with a nontreated control group. The authors found that visual acuity was significantly $(P<0.005)$ better in the treated group compared with control subjects at 3 and 6 months follow-up. Increase of intraocular pressure was present in $25 \%$ of treated patients, but was controlled with topical medication. Progression of cataract was more frequently detected in the treated group. The authors concluded that intravitreal triamcinolone acetonide may provide improvement in visual acuity in exudative agerelated macular degeneration. These clinical studies were supported by experimental studies on the effect of intravitreal cortisone on experimental subretinal neovascularization and other types of intraocular proliferation of blood vessel. ${ }^{34-37,39,42-44}$ Another recent investigation including 71 eyes with exudative agerelated macular degeneration demonstrated a significant increase in visual acuity after an intravitreal injection of $25 \mathrm{mg}$ of triamcinolone acetonide. ${ }^{48}$ The improvement in visual acuity was significant at 1 month $(P=0.04)$ and 2 months $(P=0.04)$ after the injection. About 3-5 months after the injection, visual acuity had decreased so that the visual acuity at the end of the follow-up did not differ significantly $(P=0.17)$ from the baseline values.

Altogether, 48 (66.2\%) eyes gained in visual acuity during the follow-up. ${ }^{48} \mathrm{~A}$ recent report on a single patient who repeatedly received intravitreal injections of

triamcinolone acetonide $(25 \mathrm{mg})$ demonstrated after each injection a re-increase of visual acuity during a period of several months. ${ }^{45}$ The results of the present study and of the other investigations described are partially in contrast to a recent study by Gillies $e t a l^{49}$ who found no effect of $4 \mathrm{mg}$ of intravitreal triamcinolone acetonide on the development of severe visual loss over a follow-up period of 1 year. One of the reasons for the discrepancy between the investigation performed by Gillies and colleagues and the present study may be the difference in the dosage of triamcinolone acetonide injected. Another reason may be that in the study by Gillies and colleagues, re-injections were not performed. It would fit with the results of the present study in which the peak in visual acuity occurred about 2-5 months after the injection. At the end of the follow-up, visual acuity was no longer better than prior to the intravitreal injection in the study group, and at the end of follow-up, the study group and control group no longer differed significantly in terms of the change in visual acuity. Interestingly, Gillies and coworkers found a statistically significant and therapeutically positive effect of intravitreal triamcinolone on the size of the subfoveal neovascularization 3 months after the injection. It is in agreement with experimental studies on an angiostatic effect of intravitreal cortisone on experimental subretinal neovascularization and other types of intraocular blood vessel proliferation. ${ }^{34,35-37,39}$ An additional reason for the discrepancy between the study by Gillies and colleagues and the present as well as the preceding studies may be that Gillies' investigation included patients with the classic type of subfoveal neovascularization, which is associated with a worse prognosis compared to the occult type of subfoveal neovascularization. 
Based on these preceding studies, the purpose of the present investigation was to compare the visual outcome of patients receiving an intravitreal injection of triamcinolone acetonide with the visual acuity of patients of a nonrandomized control group not receiving any treatment for exudative age-related macular degeneration. The results suggest that an intravitreal injection of $25 \mathrm{mg}$ triamcinolone acetonide improves the visual outcome during 3 months after the injection (Table 2). When comparing the patients of the study group with those of the control group, a significantly $(P<0.01)$ higher, and significantly $(P<0.01)$ more often, an increase in visual acuity was present. The differences between the study group and the control group were statistically significant for the measurements at 1 and 3 months after the injection (Table 2).

The most important limitation of the present study is its design as a nonrandomized comparative clinical investigation. The reason for assigning the patients to the study group or control group was most of the time the decision of the patient not to have an intravitreal injection with an uncertain therapeutic effect. Assuming that the decision of the patient was not mainly influenced by the findings of the macula, one might infer that the study and control group may not have markedly varied in preoperative parameters. Correspondingly, the study and control group did not differ significantly in terms of preoperative visual acuity, age, and gender (Table 1). Owing to the lack of randomization and masking, however, conclusions may not be drawn about the benefit of treatment due to observer and patient bias even if the study group and the control group were balanced. Another limitation of the study might be that, although intravitreal triamcinolone will have increased the cataract, cataract surgery was not performed in combination with nor after the intravitreal injection of triamcinolone acetonide. The vision-reducing effect of progressive cataract, however, might have hidden parts of a vision-improving effect of triamcinolone so that this limitation of the study might serve to support the conclusion of the investigation. Another limiting factor might be the relatively small number of patients included in the study. This concerns mainly the number of patients in the control group at the various times of reexamination. Despite the relatively small number of patients, however, the postinjection visual acuity was significantly better for the study group than for the control group. The small number of patients might thus support the conclusion of the study. An additional limitation of the study might be the relatively high dosage of triamcinolone acetonide injected into the eye. In all preceding studies of other study centres injecting intravitreal triamcinolone acetonide as treatment of exudative age-related macular degeneration, a dosage of
$4 \mathrm{mg}$ was used. ${ }^{28,29}$ The reason why we continued to inject $25 \mathrm{mg}$ triamcinolone acetonide was that right from the beginning of our ongoing triamcinolone investigations now involving more than 400 patients with various diseases, we have used the same dosage of $25 \mathrm{mg}$ of triamcinolone acetonide, and we have not yet seen side effects that may be attributed to the high dosage. An additional reason to take the high dosage for the present study was that in preceding studies on intravitreal use of $4 \mathrm{mg}$ of triamcinolone acetonide for patients with exudative age-related macular degeneration, the therapeutic effect has not been obvious. ${ }^{32,40}$

The main side effect of intravitreal triamcinolone acetonide observed in the present study was an elevation of intraocular pressure. Forty-nine $(43.0 \%)$ eyes developed maximal intraocular pressure measurements higher than $21 \mathrm{mmHg}$. As already described in previous studies, ${ }^{10,32,33}$ the secondary ocular hypertension could usually be treated by topical antiglaucomatous medication without the development of glaucomatous optic nerve damage.

In conclusion, the data of the present prospective comparative nonrandomized study suggest that the intravitreal injection of $25 \mathrm{mg}$ of triamcinolone acetonide may improve the visual outcome of patients with exudative age-related macular degeneration during the first 3 months after injection.

\section{References}

1 Bressler NM, Bressler SB, Fine SL. Age-related macular degeneration. Surv Ophthalmol 1988; 32: 375-413..

2 Mitchell P, Smith W, Attebo K, Wang JJ. Prevalence of agerelated maculopathy in Australia. The Blue Mountains eye study. Ophthalmology 1995; 102: 1450-1460.

3 Vingerling JR, Dielemans I, Hofman A, Grobbee DE, Hijmering M, Kramer CT et al. The prevalence of age-related maculopathy in the Rotterdam Study. Ophthalmology 1995; 102: $205-210$.

4 Schmidt-Erfurth U, Miller JW, Sickenberg M, Laqua H, Barbazetto I, Gragroudas E et al. Photodynamic therapy with verteporfin for choroidal neovascularization caused by age-related macular degeneration: results of retreatments in a phase 1 and 2 study. Arch Ophthalmol 1999; 117: 1177-1187.

5 Treatment of age-related macular degeneration with photodynamic therapy (TAP) study group. Photodynamic therapy of subfoveal choroidal neovascularization in agerelated macular degeneration with verteporfin: one-year results of 2 randomized clinical trials-TAP report. Arch Ophthalmol 1999; 117: 1329-1345.

6 Bressler NM, Treatment of Age-related macular degeneration with photodynamic therapy (TAP) study group. Photodynamic therapy of subfoveal choroidal neovascularization in age-related macular degeneration with verteporfin: two-year results of 2 randomized clinical trials-tap report 2. Arch Ophthalmol 2001; 119: 198-207. 
7 Schindler RH, Chandler DB, Thresher R, Machemer R. The clearance of intravitreal triamcinolone acetonide. Am J Ophthalmol 1982; 93: 415-417.

8 Jonas JB. Concentration of intravitreally applicated triamcinolone acetonide in aqueous humour. $\mathrm{Br} J$ Ophthalmol 2002; 86: 1066.

9 Jonas JB. Concentration of intravitreally injected triamcinolone acetonide in intraocular silicone oil. $\mathrm{Br} J$ Ophthalmol 2002; 86: 1450-1451.

10 Jonas JB, Kreissig I, Degenring RF. Secondary chronic openangle glaucoma after intravitreal triamcinolone acetonide. Arch Ophthalmol 2003; 121: 729-730.

11 Jonas JB, Söfker A. Intraocular injection of crystalline cortisone as adjunctive treatment of diabetic macular edema. Am J Ophthalmol 2001; 132: 425-427.

12 Martidis A, Duker JS, Greenberg PB, Rogers AH, Puliafitto CA, Reichel E et al. Intravitreal triamcinolone for refractory diabetic macular edema. Ophthalmology 2002; 109: 920-927.

13 Jonas JB, Kreissig I, Söfker A, Degenring RF. Intravitreal injection of triamcinolone acetonide for diabetic macular edema. Arch Ophthalmol 2003; 121: 57-61.

14 Jonas JB, Hayler JK, Söfker A, Panda-Jonas S. Intravitreal injection of crystalline cortisone as adjunctive treatment of proliferative diabetic retinopathy. Am J Ophthalmol 2001; 131: 468-471.

15 Jonas JB, Söfker A, Degenring RF. Intravitreal triamcinolone acetonide as additional tool in pars plana vitrectomy for proliferate diabetic retinopathy. Eur J Ophthalmol 2003; 13: 468-473.

16 Jonas JB, Hayler JK, Söfker A, Panda-Jonas S. Regression of neovascular iris vessels by intravitreal injection of crystalline cortisone. J Glaucoma 2001; 10: 284-287.

17 Jonas JB, Söfker A. Intravitreal triamcinolone acetonide for cataract surgery with iris neovascularisation. J Cataract Refract Surg 2002; 28: 2040-2041.

18 Greenberg PB, Martidis A, Rogers AH, Duker JS, Reichel E. Intravitreal triamcinolone acetonide for macular oedema due to central retinal vein occlusion. Br J Ophthalmol 2002; 86: $247-248$

19 Jonas JB, Kreissig I, Degenring RF. Intravitreal triamcinolone acetonide as treatment of macular edema in central retinal vein occlusion. Graef Arch Clin Exp Ophthalmol 2002; 240: 782-783.

20 Degenring RF, Kamppeter B, Kreissig I, Jonas JB. Morphologic and functional changesafter intravitreal triamcinolone acetonidefor retinal vein occlusion. Acta Ophthalmol 2003; 81: 399-401.

21 Jonas JB, Hayler JK, Panda-Jonas S. Intravitreal injection of crystalline cortisone as adjunctive treatment of proliferative vitreoretinopathy. Br J Ophthalmol 2000; 84: 1064-1067.

22 Jonas JB, Hayler JK, Panda-Jonas S. Intravitreal injection of crystalline cortisone as treatment of pre-phthisical ocular hypotony. Graef Arch Clin Exp Ophthalmol 2001; 239: 464-465.

23 Antcliff RJ, Spalton DJ, Stanford MR, Graham EM, Ffytche TJ, Marshall J. Intravitreal triamcinolone for uveitic cystoid macular edema: an optical coherence tomography study. Ophthalmology 2001; 108: 765-772.

24 Martidis A, Duker JS, Puliafito CA. Intravitreal triamcinolone for refractory cystoid macular edema secondary to birdshot retinochoroidopathy. Arch Ophthalmol 2001; 119: 1380-1383.

25 Young S, Larkin G, Branley M, Lightman S. Safety and efficacy of intravitreal triamcinolone for cystoid macular oedema in uveitis. Clin Experiment Ophthalmol 2001; 29:

2-6.

26 Degenring RF, Jonas JB. Intravitreal injection of triamcinolone acetonide as treatment of chronic uveitis. $\mathrm{Br} J$ Ophthalmol 2003; 87: 361.

27 Benhamou N, Massin P, Haouchine B, Audren F, Tadayoni $\mathrm{R}$, Gaudric A. Intravitreal triamcinolone for refractory pseudophakic macular edema. Am J Ophthalmol 2003; 135: 246-249.

28 Conway MD, Canakis C, Livir-Rallatos C, Peyman GA. Intravitreal triamcinolone acetonide for refractory chronic pseudophakic cystoid macular edema. J Cataract Refract Surg 2003; 29: 27-33.

29 Jonas JB, Kreissig I, Degenring RF. Intravitreal triamcinolone acetonide for pseudophakic cystoid macular edema. Am J Ophthalmol 2003; 136: 384-386.

30 Peyman GA, Cheema R, Conway MD, Fang T. Triamcinolone acetonide as an aid to visualization of the vitreous and the posterior hyaloid during pars plana vitrectomy. Retina 2000; 20: 554-555.

31 Jonas JB, Kreissig I, Degenring RF. Intravitreal triamcinolone as treatment for ischemic ophthalmopathy. Eur J Ophthalmol 2003; 13: 575-576.

32 Wingate RJ, Beaumont PE. Intravitreal triamcinolone and elevated intraocular pressure. Aust N Z J Ophthalmol 1999; 27: 431-432.

33 Jonas JB, Kreissig I, Degenring R. Intraocular pressure after intravitreal injection of triamcinolone acetonide. $\mathrm{Br} J$ Ophthalmol 2003; 87: 24-27.

34 Tano Y, Sugita G, Abrams G, Machemer R. Inhibition of intraocular proliferation with intravitreal corticosteroid. Am J Ophthalmol 1980; 89: 131-136.

35 Tano Y, Chandler D, Machemer R. Treatment of intraocular proliferation with intravitreal injection of tramcinolone acetonide. Am J Ophthalmol 1980; 90: 810-816.

36 Ishibashi T, Miki K, Sorgente N, Patterson R, Ryan SJ. Effects of intravitreal administration of steroids on experimental subretinal neovascularization in the subhuman primate. Arch Ophthalmol 1985; 103: 708-711.

37 Antoszyk AN, Gottlieb JL, Machemer R, Hatchell DL. The effects of intravitreal triamcinolone acetonide on experimental pre-retinal neovascularization. Graefes Arch Clin Exp Ophthalmol 1993; 231: 34-40.

38 Penfold PL, Gyory JF, Hunyor AB, Billson FA. Exudative macular degeneration and intravitreal triamcinolone. A pilot study. Aust N Z J Ophthalmol 1995; 23: 293-298.

39 Danis RP, Bingaman DP, Yang Y, Ladd B. Inhibition of preretinal and optic nerve head neovascularization in pigs by intravitreal triamcinolone acetonide. Ophthalmology 1996; 103: 2099-2104.

40 Challa JK, Gillies MC, Penfold PL, Gyory JF, Hunyor AB, Billson FA. Exudative macular degeneration and intravitreal triamcinolone: 18 month follow up. Aust N Z J Ophthalmol 1998; 26: 277-281.

41 Danis RP, Ciulla TA, Pratt LM, Anliker W. Intravitreal triamcinolone acetonide in exudative age-related macular degeneration. Retina 2000; 20: 244-250.

42 Penfold PL, Wong JG, Gyory J, Billson FA. Effects of triamcinolone acetonide on microglial morphology and quantitative expression of MHC-II in exudative age-related macular degeneration. Clin Exp Ophthalmol 2001; 29: 188-192.

43 Ciulla TA, Criswell MH, Danis RP, Hill TE. Intravitreal triamcinolone acetonide inhibits choroidal 
neovascularization in a laser-treated rat model. Arch Ophthalmol 2001; 119: 399-404.

44 Penfold PL, Wen L, Madigan MC, King NJ, Provis JM. Modulation of permeability and adhesion molecule expression by human choroidal endothelial cells. Invest Ophthalmol Vis Sci 2002; 43: 3125-3130.

45 Jonas JB, Kreissig I, Degenring RF. Repeated intravitreal injections of triamcinolone acetonide as treatment of progressive exudative age-related macular degeneration. Graef Arch Clin Exp Ophthalmol 2002; 240: 873-874.

46 Penfold PL. Intravitreal triamcinolone in recurrence of choroidal neovascularisation. Br J Ophthalmol 2002; 86: 600-601.
47 Ranson NT, Danis RP, Ciulla TA, Pratt L. Intravitreal triamcinolone in subfoveal recurrence of choroidal neovascularisation after laser treatment in macular degeneration. Br J Ophthalmol 2002; 86: 527-529.

48 Jonas JB, Kreissig I, Hugger P, Sauder G, Panda-Jonas S, Degenring $\mathrm{R}$. Intravitreal triamcinolone acetonide for exudative age-related macular degeneration. $\mathrm{Br} \mathrm{J}$ Ophthalmol 2003; 87: 462-468.

49 Gillies MC, Simpson JM, Luo W, Penfold P, Hunyor AB, Chua $W$ et al. A randomized clinical trial of a single dose of intravitreal triamcinolone acetonide for neovascular agerelated macular degeneration: one-year results. Arch Ophthalmol. 2003; 121: 667-673. 